\title{
Seasonal indoor radon studies in buildings of Accra Metropolis of Greater Accra region of Ghana
}

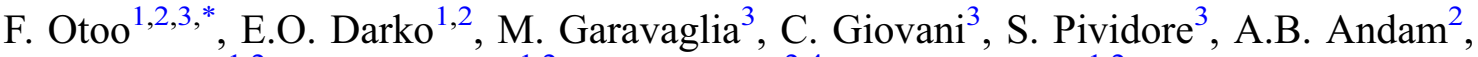 \\ J.K. Amoako ${ }^{1,2}$, O.K. Adukpo ${ }^{1,2}$, J.B. Tandoh ${ }^{2,4}$ and S. Inkoom ${ }^{1,2}$ \\ ${ }^{1}$ Radiation Protection Institute, Ghana Atomic Energy Commission, P.O. Box LG 80, Legon-Accra, Ghana. \\ 2 School of Nuclear and Allied Sciences, University of Ghana, P.O. Box AE1, Atomic Campus, Accra, Ghana. \\ ${ }^{3}$ Centro Regionale di Radioprotezione, Agenzia Regionale la Protezione dell' Ambientale del Friuli Venzia Giulia, via 42 Colugna, \\ 33100 Udine, Italy. \\ ${ }^{4}$ National Nuclear Research Institute, Ghana Atomic Energy Commission, P.O. Box LG 80, Legon-Accra, Ghana.
}

Received: 8 February 2018 / Accepted: 9 May 2018

\begin{abstract}
Indoor radon concentration for annual, rainy and dry season have been studied in 228 buildings which includes bedroom, kitchen, sitting room, laboratories and offices in Accra metropolis of Greater Accra of Ghana. The passive radon CR-39 SSNTD was used for this study. The cumulative frequency distribution, normalizing Q-Q plots, Kolmogorov-Smirnov and Shapiro-Wilk statistical test showed that the result of both workplaces and dwellings are not normally distributed. The strong positive correlation between the two seasons occurred at 95\% confidence level with 2 tailed. The rainy season recorded highest coefficient variation of $\mathrm{r}^{2}=0.982$. Statistical analysis of median (39.3), AM (103.4), GM (57.9) and GSD (3.2) for rainy season were greater than that of the dry season of median (26.9), AM (88.2), GM (49.2) and GSD (2.8) respectively. Rainy season was found to contain high radon concentrations than the dry season for all the studied locations. In general, workplace had radon concentration far greater than dwellings. The results obtained from this study ranged between 13.6 to $533.7 \mathrm{~Bq} / \mathrm{m}^{3}$, out of which $9.6 \%, 12.7 \%$ and $3.5 \%$ were found to be greater than action levels proposed by WHO, EC and ICRP.
\end{abstract}

Keywords: CR-39 / indoor radon / workplace / dwellings

\section{Introduction}

The greatest fraction of natural radiation exposure to the public and workers result from indoor inhalation of radon gas. Indoor radon concentrations in buildings depends on a number of factors such as the type of building materials, geology, occupant life style, climate and dwelling engineering, etc.

The human lungs is exposed to alpha particles through the inhalation of Radon gas. Radon is a gas that emanates from soil and rock in the ground as well as building materials as a result of decay series of ${ }^{238} \mathrm{U}$, and form particulate radionuclides that can deposit in the lungs (Nazaroff, 1992). The radon exposure of humans may increase for those living in buildings constructed from materials with high uranium concentration values above normal background levels (Esposito et al., 2004). The Surgeon General of the United States has warned that radon is the second leading cause of

*Corresponding author: kwaotoo@yahoo.com lung cancer in the United States apart from smoking cigarette (EPA, 2003).

The annual and seasonal indoor radon studies in buildings were carried out all over the world to determine the levels and suggest recommendations to reduce the radon emanation from the prone areas (EC, 1990; ICRP, 1993; Pinel et al., 1995; EPA, 2003; IAEA, 2003; Colgan et al., 2004; Esposito et al., 2004; Ioannides et al., 2009; Venoso et al., 2009; WHO, 2009; Abd El-Zaher, 2011; Iqbal et al., 2011, 2012; Cucos et al., 2012; Miles et al., 2012; Stojanovska et al., 2012; Brauner et al., 2013). Most of these results have revealed high indoor radon concentrations in winter and the lowest in summer seasons. Even though Ghana experiences seasons which differ from Europe, America, North Africa and the rest of the world, the authors do not expect a very different radon level pattern for the Ghanaian seasons. Ghana experiences a typical tropical climate of rainy season from April to September with a lot of rains and coolest weather while dry season occurs in October to March, very hot and dusty (Dickson and Benneh, 2004; UNDP, 2013). Indoor radon concentration in buildings, with respect to 


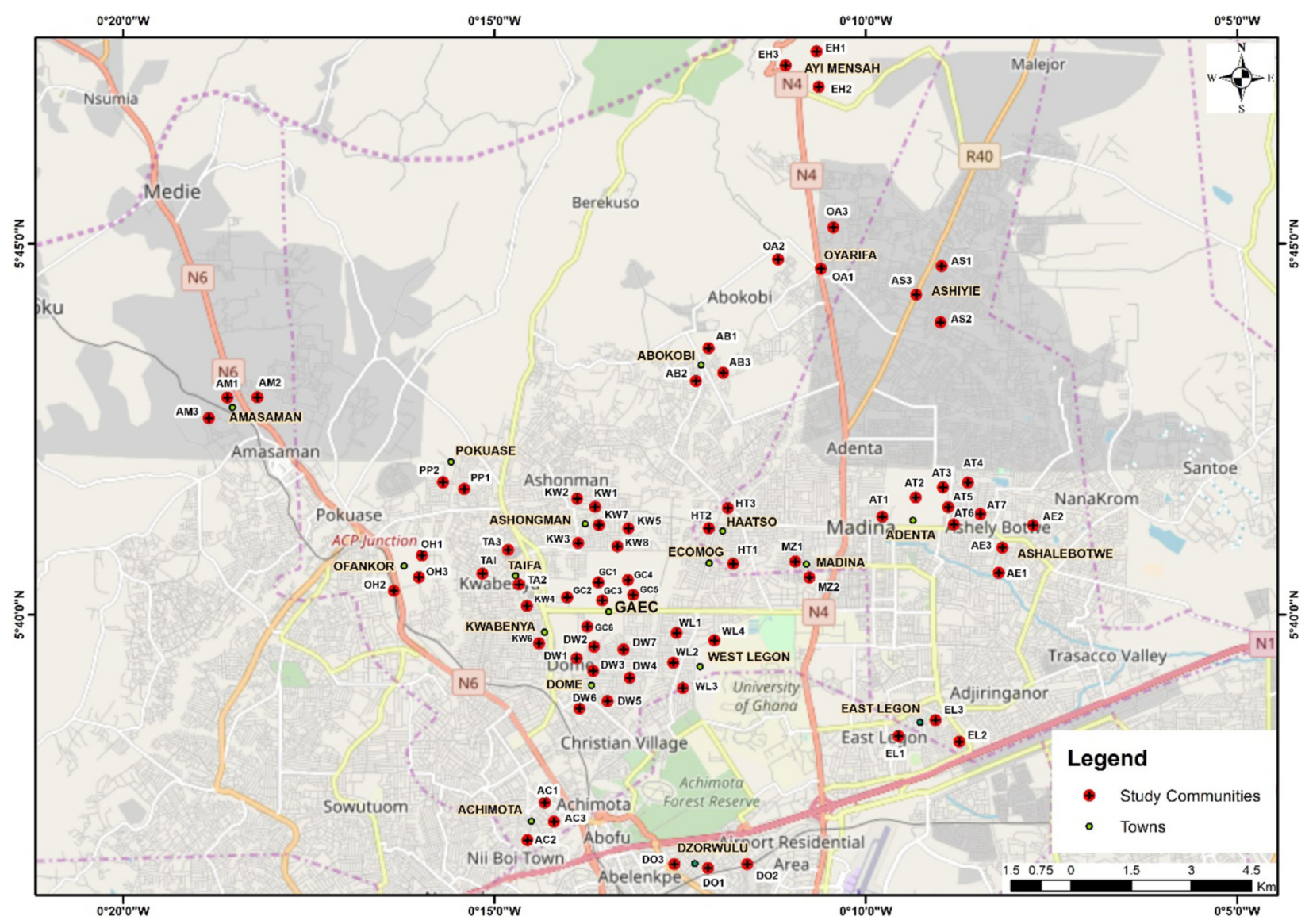

Fig. 1. Map of indoor radon study locations.

rainy and dry weather conditions, have not yet been evaluated in Ghana. At the present time, Ghana does not have national guidelines specifying the acceptable radon levels in both workplaces and dwellings but have been using international action levels and limits. Most studies on radon in Ghana have focused on water, soil and buildings but not in offices and laboratories (Andam, 1994; Darko et al., 2010; Ansre et al., 2018). The Ghana Atomic Energy Commission (GAEC) houses numerous laboratories and offices with staff strength of almost 700 people. Due to the eight (8) hours daily working schedule for all staff, one can classify the offices as "long occupancy" sites. This necessitates the importance of carrying out indoor radon measurements at these offices and laboratories together with some residential communities within the region for an adequate risk assessment. This study is part of a broader project that has just been initiated on public and occupational radiation exposure control programme in building materials, workplaces, dwellings, food and environmental samples in Ghana with the objective to establish national radioactivity levels. The authors hope the outcome of this study will aid in decision-making processes in the setting up national guidelines for the control of radon exposure in buildings of Ghana. In this study, CR-39 have been applied in the study of indoor radon concentration in workplace and dwellings for the assessment of annual, rainy and dry seasons to ascertain whether there exist any significant differences in an indoor radon concentration between these seasons in Accra Metropolis of Greater Accra region of Ghana.

\section{Materials and methods}

\subsection{Description of the study areas}

The study area is located in the Greater Accra region of Ghana and lies between longitudes $0^{\circ} 20^{\prime} 0^{\prime \prime} \mathrm{W}$ and $0^{\prime} 5^{\prime} 0^{\prime \prime} \mathrm{W}$ and latitudes $5^{\circ} 40^{\prime} 0^{\prime \prime} \mathrm{N}$ and $5^{\circ} 45^{\prime} 0^{\prime \prime} \mathrm{N}$, as shown in Figure 1. It is bounded on the North and West by the Akwapin-Togo ranges and Ga district, respectively, on the East by Tema plain and on the South by the Gulf of Guinea. The Accra Plain is generally flat and undulating with a few isolated icebergs that seldom rise $70 \mathrm{~m}$ above mean sea level. The region enjoys a year round tropical climate, but it does have two main climate seasons, namely rainy and dry. The rainy season start from April to September with the major rains occurring in June while the minor in September. The coolest weather happens in August with average daily temperature of $23.2^{\circ} \mathrm{C}$. Generally, the rainfall in the Accra Plains is low with mean annual rainfall of approximately $900 \mathrm{~mm}$ per annum. The dry season occurs from the months of October to March. January-March period is characterized by dry and dusty weather conditions with wind, and blows from the Sahara Desert over West Africa into the Gulf of Guinea with lower humidity resulting in hotter days and cooler nights. Average daily temperatures ranges from $31.1^{\circ} \mathrm{C}$ during the day to $24^{\circ} \mathrm{C}$ at night with a relative humidity between 77 percent and 85 percent. The annual mean temperature within the region is $26.5^{\circ} \mathrm{C}$ (Dickson and Benneh, 2004; UNDP, 2013). 


\subsection{Geology of the study area}

The geology of the study area is made up of different types of rocks and soils. The main rock types of the study area are Precumbrian Dahomeyan schists, granodiorites, granitic gneiss and amphibolites to late Precambrian Togo series, comprising mainly of quartzite, phillites, phylitones and quartz breccias (Kesse, 1985; Dickson and Benneh, 2004). The soil of the study area is classified into four main groups:

- drift materials resulting from deposits by windblown erosion;

- alluvial and marine motted clays of comparatively recent origin derived from underlying shales;

- residual clays and gravels derived from weathered quartzites, gneiss and schist rocks;

- lateritic sandy clay soils derived from weathered Accraian sandstone bedrock formations.

In many low lying poorly drained areas, pockets of alluvial 'black cotton' soils are found. These soils have a heavy organic content, expand, and contract readily, causing major problems with foundations and footings. In some areas, lateritic soils are strongly acidic and when saturated are prone to attack concrete foundations causing honeycombing. Near the foothills are the large areas of alluvial laterite gravels and sands (Kesse, 1985; Dickson and Benneh, 2004). Many of these deposits are being exploited in an uncontrolled manner for constructional purposes.

\subsection{Characteristics and properties of the buildings}

The buildings chosen for this study were generally built with sandcrete, concrete, bricks from clay and wooden structures. Out of 102 studied locations at the workplace, $90.3 \%$ of them were storey with concrete walls, cemented gravels and tiles floors, $8.4 \%$ bungalows which consist of sandcrete wall and the remaining $1.3 \%$ consist of wooded walls, cement gravels and tile floors. All the buildings at the workplace were older than 50 years.

A total of 126 places were studied for dwellings. Out of this, $86.6 \%$ were made of sandcrete walls with tile floors, while the remaining $1.4 \%$ were made of bricks with tile floor. Majority of these dwellings (94\%) studied were single floor bungalows, while the rest $(0.6 \%)$ were storey buildings with not less than 15 years of existence since constructed.

The number of rooms per building ranged from one to four for dwellings while the workplace had more than ten rooms per building. All the monitored dwellings did not have air conditioning systems installed while all work place (offices, and laboratories) had air conditioners fully installed. The offices and laboratories contain one to ten workers in each room. On average, these workers work eight hours per day and five days in a week.

\subsection{Distribution and etching of the radon detectors}

Two hundred and twenty eight (228) CR-39 detectors were used for this study. Indoor radon measurements were carried out in 76 offices, 26 laboratories and 126 dwellings for annual

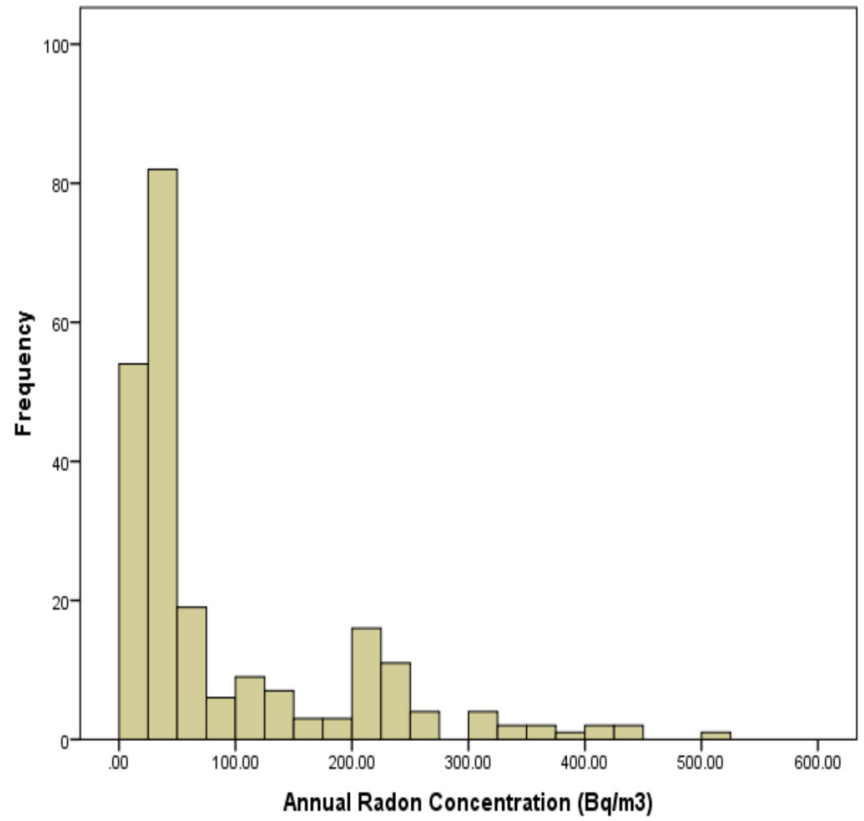

Fig. 2. Frequency distribution of indoor radon concentration for dwellings and workplace.

and seasonal studies (rainy: April-September; dry: OctoberMarch). Indoor radon concentrations for the studied buildings were randomly selected within the premises of GAEC and residential communities in Accra Metropolis of greater Accra region of Ghana as shown in Figure 1. In each building, a detector was placed either in a bedroom, kitchen, sitting room, office or laboratory, at a height of 1 to $1.5 \mathrm{~m}$ above the floor, at a distance greater than $0.5 \mathrm{~m}$ from each wall, and at a minimum of $15 \mathrm{~cm}$ from any other objects for a period of 12 months and 6 months in dry and rainy seasons. In order to understand the radon concentration differences between the buildings, the working hours, ventilation system, frequency of the aeration, age and the building structures were noted during the analysis of the results. Exposed radon detectors were sent to Centro Regionale di Radioprotezione, Agenzia Regionale la Protezione dell' Ambientale del Friuli Venzia Giulia (ARPA FVG), Udine, Italy for analysis. The detectors were removed and etched in $6.25 \mathrm{~N}$ solution of $90^{\circ} \mathrm{C}$ for 4 hours and 15 minutes at constant temperature followed by 15 minutes neutralization with $36 \mathrm{ml}$ of $96 \%$ diluted acetic acid. Finally, detectors were washed in distilled water for 15 minutes to wash any excess chemicals and dried for 4 days. The latent tracks formed on the detectors were scanned and counted in 144 fields using an optical microscope of $40 \times$ magnification objective lens. The tracks density left on track films were then used to evaluate the indoor radon concentration.

\section{Results and discussions}

The distribution of annual indoor radon concentration of 228 buildings is shown on the histogram in Figure 2. The obtained results are summarized in Table 1. 
Table 1. Test of normality of radon data.

\begin{tabular}{llllllll}
\hline & \multicolumn{3}{c}{ Kolmogorov-Smirnov } & & \multicolumn{3}{c}{ Shapiro-Wilk } \\
\cline { 2 - 4 } \cline { 7 - 8 } \cline { 7 - 8 } & Statistic & NR & Sig & & Statistic & NR & Sig \\
\hline Dwellings & .180 & 126 & .000 & & .886 & 126 & .000 \\
Workplace & .109 & 102 & .005 & & .928 & 102 & .000 \\
\hline
\end{tabular}

NR: Number of Rooms.

\subsection{Normality of the radon data}

Two approaches were adapted to addressing the normality of all radon data acquired. The graphical approach which involved both cumulative frequency distribution and normalizing Q-Q plots were utilized for the initial testing of the normality of studied data. The findings were further investigated using Kolmogorov-Smirnov and Shapiro-Wilk tests which represented the statistical approach.

Figures 3 and 4 attempt to test the normality of the radon data for dwellings and workplace with a cumulative frequency distribution plot. At a glance, one will be tempted to conclude that the cumulative plots, especially Figure 3, is normally distributed, but upon further probing, after a Q-Q plot was performed, as shown in Figures 5 and 6, it was observed that most of the data deviated from the diagonal expected line for normalized data.

The authors went further to perform statistical method using both Kolmogorov-Smirnov and Shapiro-Wilk test for normality. Unfortunately the dwellings data failed this test as the significant value $(0.000)$ shown in Table 1 , is less than 0.05 , which infers that the data is not normal. This same procedure was repeated for the radon data for the workplace and it also failed the normality test as shown in Table 1 .

The reason for the lack of the normal distribution for the result in both workplace and residential dwellings could be attributed to the different types of building materials, dwelling engineering, occupant life styles, frequency of aeration and variation of the different types of building and different storey levels of the studied buildings.

\subsection{Radon concentration in dwellings and offices}

The annual values of indoor radon concentration ranged from $13.6-533.7 \mathrm{~Bq} / \mathrm{m}^{3}$, of which $166 \mathrm{dwellings}$ revealed indoor radon concentrations lower than $100 \mathrm{~Bq} / \mathrm{m}^{3}$. The lowest and highest values were recorded in offices as shown in Table 2. The lowest indoor radon concentration was recorded in wooden dwellings as presented in Table 4. This could be attributed to the fact that wood does not originate directly from the earth crust and therefore have lower uranium decay product of radon, as compared to rocks and soils. It could be also credited to the location (third floor) of the room as shown in Table 3, since radon gas is always higher at ground floor as compared to top level. Concrete buildings recorded the highest radon levels which can be linked to the some of the emanation of radon gas from the building materials.

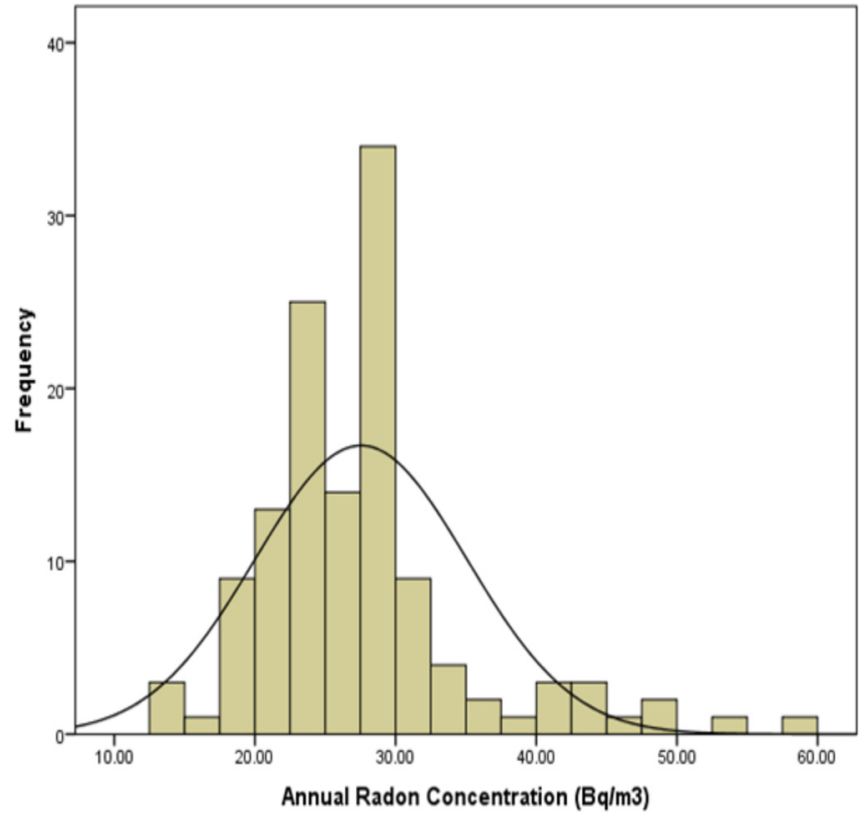

Fig. 3. Cumulative frequency distribution of annual radon levels for dwellings.

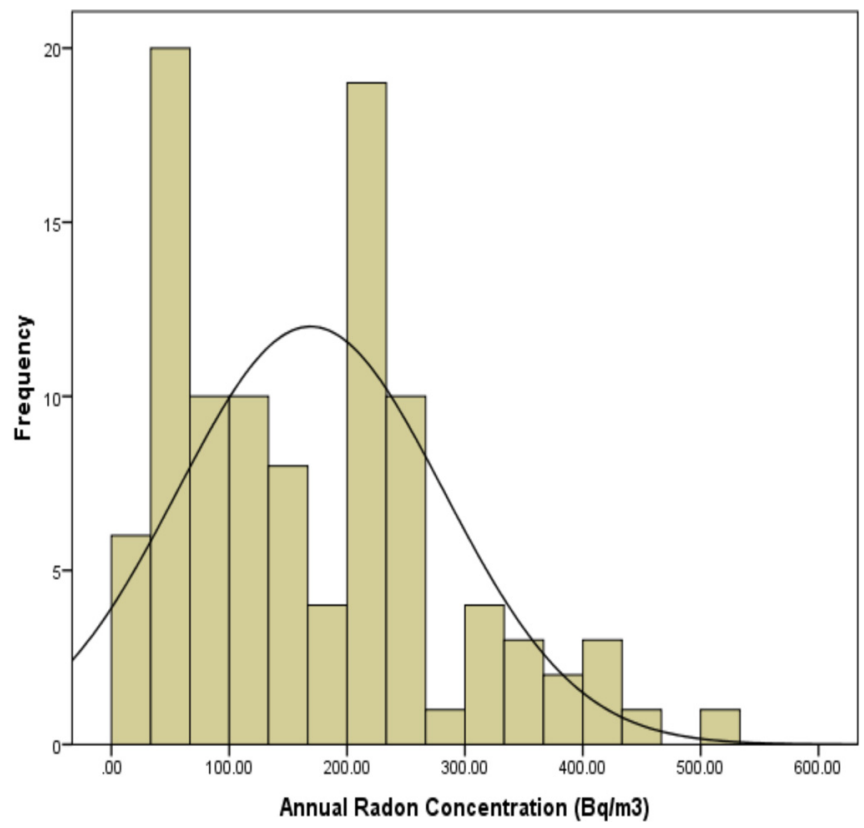

Fig. 4. Cumulative frequency distribution of annual radon levels for workplace.

The action levels (i.e. the levels above which actions are suggested to reduce the radon concentration) recommended by: - World Health Organization (WHO) is $100 \mathrm{~Bq} / \mathrm{m}^{3}$ (WHO, 2009);

- European Commission for future and existing dwellings: 200 and $400 \mathrm{~Bq} / \mathrm{m}^{3}$ (EC, 1999);

- the International Commission on Radiological Protection: $500 \mathrm{~Bq} / \mathrm{m}^{3}$ for workplaces (ICRP, 1993).

Venoso et al. state that the national level for workplace indoor radon concentration is $500 \mathrm{~Bq} / \mathrm{m}^{3}$, which is adopted by 


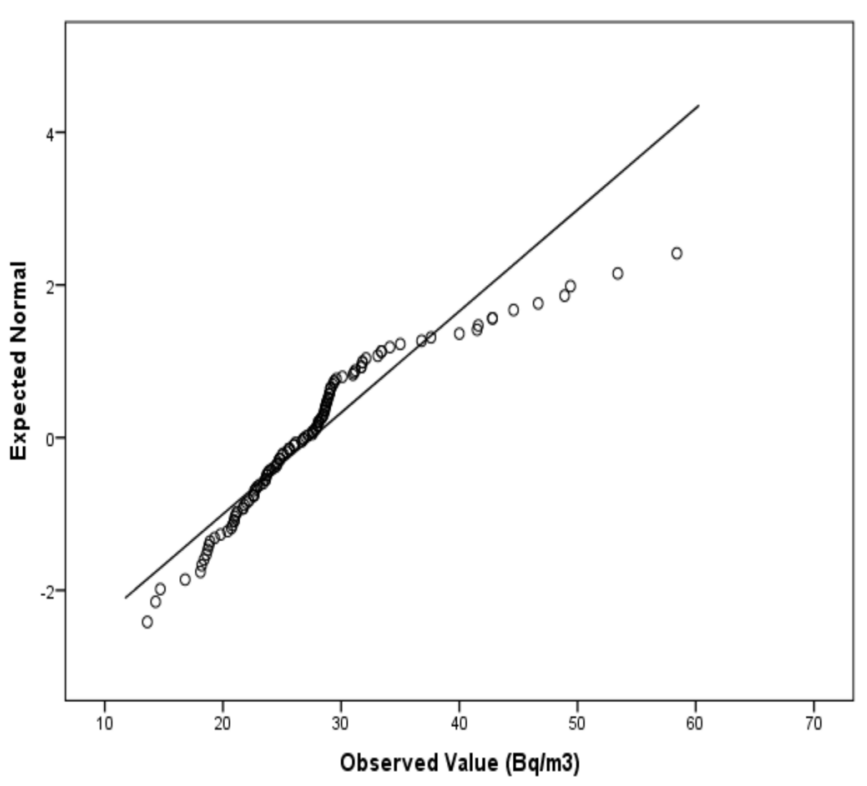

Fig. 5. Q-Q plot of annual indoor radon concentration for dwellings.

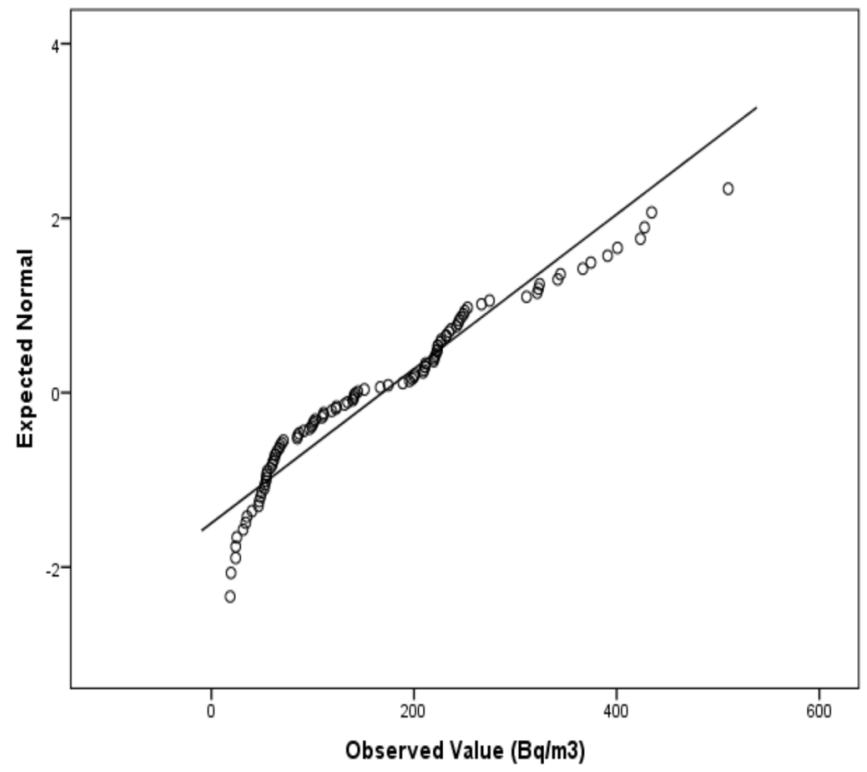

Fig. 6. Q-Q plot of annual indoor radon concentration data for workplace.

Table 2. Summary of results of annual radon concentration at different location in buildings.

\begin{tabular}{|c|c|c|c|c|c|c|}
\hline & \multicolumn{6}{|c|}{ Monitored location } \\
\hline NR of survey & 54 & 41 & 32 & 76 & 26 & 228 \\
\hline Median & 29.1 & 23.4 & 26.8 & 125.1 & 204.9 & 33.3 \\
\hline $\mathrm{AM}$ & $32.2 \pm 1.5$ & $23.3 \pm 1.4$ & $26.5 \pm 1.5$ & $157.6 \pm 7.6$ & $167.1 \pm 8.2$ & $91.7 \pm 6.4$ \\
\hline$\% \mathrm{NR}>100$ & 0 & 0 & 0 & 24.0 & 19.2 & 9.6 \\
\hline$\% \mathrm{NR}>200$ & 0 & 0 & 0 & 21.3 & 50 & 12.7 \\
\hline$\% \mathrm{NR}>400$ & 0 & 0 & 0 & 14.7 & 3.8 & 3.5 \\
\hline
\end{tabular}

AM: Arithmetic Mean; GM: Geometric Mean; GSD: Geometric Standard Deviation.

Table 3. Summary of annual radon concentration at different storey levels.

\begin{tabular}{|c|c|c|c|c|c|}
\hline & \multicolumn{5}{|c|}{ Storey Level } \\
\hline NR & 3 & 48 & 28 & 21 & 13 \\
\hline Median & 344.0 & 233.0 & 63.1 & 41.9 & 28.8 \\
\hline $\mathrm{AM}$ & $314.2 \pm 15.6$ & $256.2 \pm 12.6$ & $52.0 \pm 2.4$ & $36.0 \pm 1.6$ & $31.0 \pm 1.4$ \\
\hline GM & 306.7 & 237.2 & 46.8 & 33.1 & 29.6 \\
\hline$\% \mathrm{NR}>100$ & 0 & 71.2 & 0.4 & 0 & 0 \\
\hline$\%$ NR > 200 & 67 & 56.3 & 7.7 & 0 & 0 \\
\hline$\%$ NR > 400 & 33 & 20.8 & 0 & 0 & 0 \\
\hline
\end{tabular}


Table 4. Summary of annual radon concentration in buildings with different types of building materials.

\begin{tabular}{lllll}
\hline & \multicolumn{4}{c}{ Building materials } \\
\cline { 2 - 5 } & Sandcrete & Concrete & Brick & Wooden \\
\hline NR & 122 & 86 & 11 & 6 \\
Range $\left(\mathrm{Bq} / \mathrm{m}^{3}\right)$ & $16.8-427.5$ & $18.5-533.7$ & $28.4-58.4$ & $13.6-18.4$ \\
Median & 27.6 & 140.6 & 44.6 & 15.6 \\
AM & $42.8 \pm 2.6$ & $160.1 \pm 7.8$ & $44.4 \pm 3.2$ & $15.7 \pm 1.7$ \\
GM & 30.9 & 126.6 & 43.6 & 15.6 \\
GSD & 1.4 & 5.3 & 2.2 & 1.1 \\
$\%$ NR $>100$ & 35 & 40 & 0 & 0 \\
$\%$ NR $>200$ & 22 & 31 & 0 & 0 \\
$\% \mathrm{NR}>400$ & 0 & 11 & 0 & 0 \\
\hline & & & &
\end{tabular}

the Italian law (D. Lgv 241/2000) from the ICRP action level (Venoso et al., 2009). The percentages of the rooms that exceed the reference levels are also included in the tables.

Radon exposure seems to be significantly different in magnitude in the offices and the laboratories of GAEC as compared to the dwellings in residential communities within the metropolis. Considering the geological and weather variations, the Geometric mean of radon (GM) in the studied areas was found to be $118.4 \mathrm{~Bq} / \mathrm{m}^{3}$ in offices and $142.1 \mathrm{~Bq} / \mathrm{m}^{3}$ in laboratories. These values were found to be higher than the GM values of the bedroom, kitchen and sitting rooms which were $31.3 \mathrm{~Bq} / \mathrm{m}^{3}, 23.4 \mathrm{~Bq} / \mathrm{m}^{3}$ and $26.8 \mathrm{~Bq} / \mathrm{m}^{3}$ in dwellings, respectively. However, this study found that most of the offices and laboratories in the workplace were in dense environment, resulting in poorer ventilation than in most residential locations that had access to air flow during the daytime through open doors and windows. GM of bedroom, kitchen and sitting room were found to be less while offices and laboratories obtained values for the studies far greater than the world mean value of $39 \mathrm{~Bq} / \mathrm{m}^{3}$ proposed by UNSCEAR (2014). This can be attributed to the frequent opening of the windows and doors of dwellings for exchange of air with the outdoor environment. The highest average indoor radon concentration of $533.7 \mathrm{~Bq} / \mathrm{m}^{3}$ was found in ground level of the concrete structure of more than 50 years old while the lowest result of $13.6 \mathrm{~Bq} / \mathrm{m}^{3}$ was measured in the third floor of wooden structure of less than 13 years. This is illustrated in Tables 3 and 4.

The building parameters were also taken into consideration during the evaluation of the result by examining factors such as the buildings' age, room type and ventilation system, floor level, presence of basement and the type of windows. One can attribute higher radon levels in older buildings to the structural deterioration and cracks in ground floors, causing higher radon emission gas from underlying soil of the buildings into the rooms. It is important to mention that the presence or absence of basement is significant only for the ground floor values. This finding could be attributed to the fact that the indoor radon concentration is mainly dependent on the underlying soil properties. It was found out that buildings with ventilation systems such as air conditions and fans had higher values of indoor radon concentrations, as compared to buildings with no ventilation system. It can be attributed to the fact that both windows and doors are normally closed. This will lead to build up of radon gas while rooms with no ventilation system,

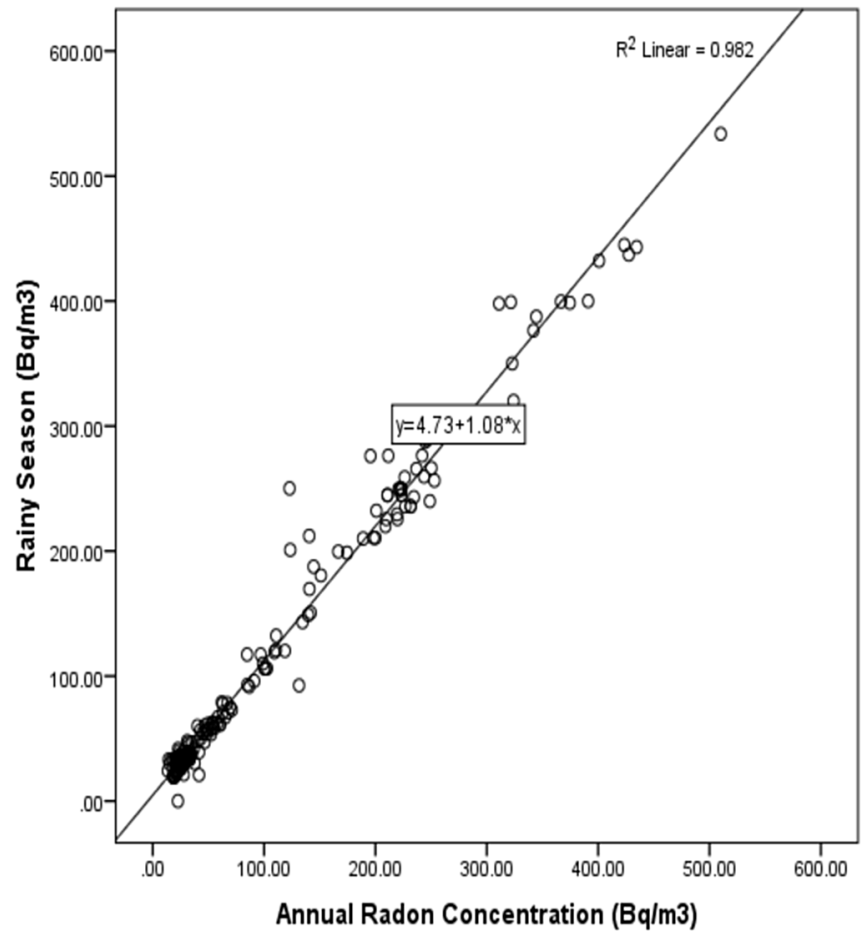

Fig. 7. Correlation between rainy and annual indoor radon concentration.

windows and doors are always open for exchange of external outdoor air in order to keep the rooms warm. This will also result in less radon concentration as compared to the room with the ventilation systems.

\subsection{Seasonal indoor radon variation}

Pearson's linear correlation coefficient (r) was computed for measured annual and seasonal radon levels for both workplace and dwellings as shown in Figure 7 and 8. The IBM SPSS v20 statistical tool was used. There was a strong positive correlation between the two seasons, with very small statistical correlation coefficient variation of 0.006 between the rainy and dry season, as shown in Figures 7 and 8 . This could be due to marginal changes between the differences in the average daily and annual temperatures (UNDP, 2013). It can also be attributed to Harmattan period that occurs within the dry season. Even though average temperature is high during the day, inhabitants closed their windows and doors to prevent dust from entering the rooms. This situation could lead to building up of radon gas in the rooms. From this study, the highest correlation coefficient, $\mathrm{r}^{2}=0.982$, was found to exist between the rainy season and the annual. Indicating that, rainy season correlate well with annual season. This result is useful for further studies, where it would be possible to estimate the annual indoor radon studies based on seasonal measurements. It also indicated that the prediction of the average annual radon concentration is best estimated from the rainy season.

Radon levels showed high concentrations for measurements done in the rainy seasons than that recorded in dry season for all the studied locations. This is illustrated in Figure 9. In the rainy seasons, average temperatures 


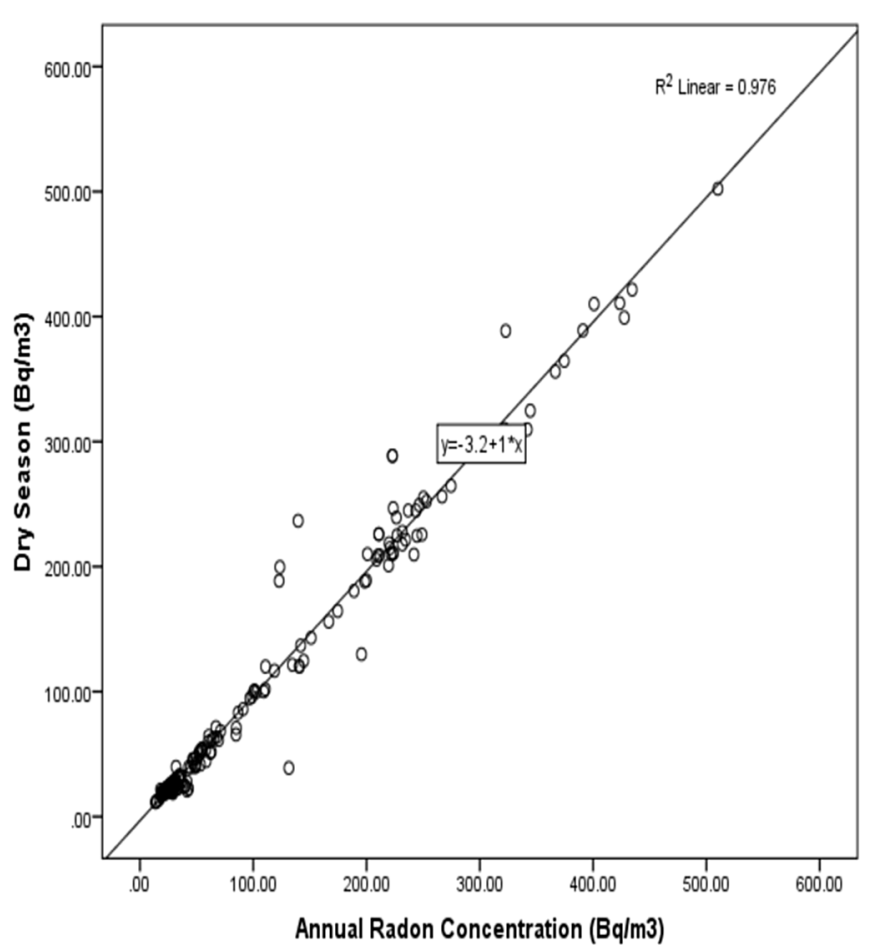

Fig. 8. Correlation between dry season and annual indoor radon concentration.

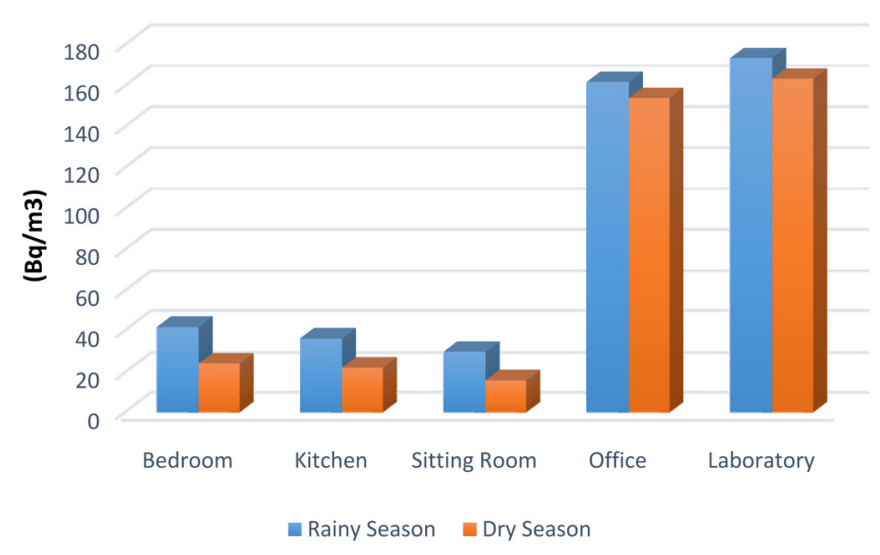

Fig. 9. Geometric mean indoor radon concentration and monitored locations.

drops, making the weather a bit cold. This forces inhabitants in most houses to keep their windows closed (reduce ventilation), and as a results allow radon gas to accumulate in their rooms.

The result showed that there was significant difference between the seasonal variations in the monitored locations. The highest seasonal GM recorded in residential bedroom and workplace laboratory shown in Figure 9 could be attributed to the less-frequent opening of the windows during the night for bedrooms and smaller window size as well as less opening of windows for laboratories during working hours. It could be also attributed to the number of rooms monitored, since the offices recorded the highest number as compared to the laboratories.

\section{Conclusion}

The annual average indoor radon concentrations for buildings in Ghana Atomic Energy Commission and dwellings in residential communities in Accra Metropolis of greater Accra region of Ghana have been studied to range from 13.6$533.7 \mathrm{~Bq} / \mathrm{m}^{3}$. Radon levels measured for all dwellings were far below the WHO proposed action level. But workplace obtained indoor radon concentration of which 9.6\%, $12.7 \%$ and $3.5 \%$ of the studied buildings were greater than action levels proposed by WHO, EC and ICRP, indicating that not all the buildings in the study areas of Accra Metropolis are negligible. The results from this study have revealed the strong dependency of indoor radon concentrations on the characteristics and type of the building (storey or ground level). Indoor radon concentration was found out to be higher in the ground floor without basement. The result showed that indoor radon concentration slightly varied with the seasons in the year. The highest indoor radon concentration was found in the rainy season, while the lowest concentration occurred in dry season. This could be attributed to the complete closing of windows during the raining season. In general, offices and laboratories had average indoor radon concentration far greater than the bedroom, kitchen and sitting room. With these findings, one can recommend the ventilation systems at some offices and laboratories to be quickly improved to curtail any possible future health risks due to inhalation of high levels of radon gas.

Future studies with respect to study period such as OctoberDecember, January-March, April-June and July-September is highly recommended in order to predict annual indoor radon concentration, without detailed radon measurements for the whole year. It will also help to know level of indoor radon exposure within these periods. The data acquired from the studies will be very important in formulating guidelines for radon exposure map and strategy for the control of radon exposure in buildings within Accra metropolis of greater Accra region.

Acknowledgement. The authors are very grateful to the staff of Centro Regionale di Radioprotezione, Agenzia Regionale la Protezione dell' Ambientale del Friuli Venzia Giulia, Udine, Italy for their assistance and the use of their facilities for this study. This research was supported by funding from the International Atomic Energy Agency (IAEA) in the form of fellowship training. The authors are also grateful to the Ghana Atomic Energy Commission (GAEC) and resident of Accra Metropolis for given permission to use their premises for this study.

\section{References}

Abd El-Zaher M. 2011. Seasonal variation of indoor radon concentration in dwellings of Alexandria city, Egypt. Radiat. Prot. Dosim. 143(1): 56-62.

Andam AB. 1994. Radon levels in sub-soil and local building materials. J. Radio. Prot. 14: 137.

Ansre Miyittah CY, Miyittah MK, Andam AB, Dodor DE. 2018. Risk assessment of radon in the South Dayi District of the Volta Region, Ghana. J. Radiat. Res. Appl. Sci. 11: 10-17.

Brauner EV, Rasmussen TV, Gunnarsen L. 2013. Variation in residential radon levels in new Danish homes. Indoor Air 23: 311-317. 
Colgan, PA, Madden JS, Synnott H, Fennell S, Pollard D, Fenton D. 2004. Current status of programmes to measure and reduce radon exposure in Irish workplaces. J. Radiol. Prot. 24: 121-129.

Cucos (Dinu) A, Cosma C, Dicu T, Begy R, Moldovan M, Papp B, Niţă D, Burghele B, Sainz C. 2012. Thorough investigations on indoor radon in Băiţa radon-prone area (Romania). Sci. Tot. Environ. 431: 78-83.

Darko EO, Adukpo OK, Fletcher JJ, Awudu AR, Otoo F. 2010. Preliminary studies on ${ }^{222} \mathrm{Rn}$ concentration in ground water from selected areas of the Accra metropolis in Ghana. J. Radioanal. Nucl. Chem. 283: 507-512.

Dickson KB, Benneh G. 2004. A new geography of Ghana. London, UK: Longmans Group Limited.

EC. 1990. Commission recommendation of 21-2-1990 on the protection of the public against indoor exposure to radon (90/ 143/Euratom). Off. J. Eur. Comm. L80: 26-28.

EPA. 2003. Assessment of risks from radon in homes, 402-R-03-003. Washington: U.S. Environmental Protection Agency.

Esposito AM, Ambrosio M, Balzano E, Gialanella L, Pugliese M, Roca V, Romano M, Sabbarese C, Venoso G. 2004. The ENVIRAD project: a way to control and to teach how to protect from high indoor radon level. In: Proceeding of the Sixth International Conference on High Levels of Natural Radiation and Radon Areas, September 6-10. Osaka, Japan.

IAEA. 2003. Radiation protection against radon in workplaces other than mines, IAEA Safety Report Series No. 33. Vienna, Austria.

ICRP. 1993. Protection against radon-222 at home and at work, ICRP Publication, vol. 65, pp. 1-262. Oxford: Pergamon Press.

Ioannides K, Patiris D, Papachristodoulou C. 2009. Indoor radon concentration in workplace and dwellings in North-Western Greece. Radioprotection 44(5): 165-169
Iqbal A, Baig MS, Akram M, Khan S. 2011. Indoor radon concentration: impact of geology in the Kashmir earthquakeaffected Bagh area, Azad Jammu and Kashmir, Pakistan. Radioprotection 46(3): 373-385.

Iqbal A, Shahid Baig M, Akram M, Qureshi AA. 2012. Indoor radon concentration levels, gamma dose rates and impact of geology-A case study in Kotli, State of Azad Jammu and Kashmir, sub-Himalayas, in Pakistan. Radioprotection 45(4): 523-535.

Kesse GO. 1985. The mineral and rock resources of Ghana. Rotterdam, Boston: A.A Balkema.

Miles JCH, Howarth CB, Hunter N. 2012. Seasonal variation of radon concentrations in UK homes. J. Radiol. Prot. 32: 275-287.

Nazaroff WW. 1992. Radon transport from soil to air. Rev. Geophys. 30: $137-160$.

Pinel J, et al. 1995. Seasonal correction factors for indoor radon measurements in the United Kingdom. Radiat. Prot. Dosim. 58: $127-132$.

Stojanovska Z, Blazo B, Mimoza R, Zora SŽ, Zoran C, Jovan J. 2012. Annual and seasonal variations of indoor radon concentration in Skopje, Republic of Macedonia. Safety Eng. 2(4): 221-225.

UNDP. 2013. Climate change country profile: Ghana. ncsp.undp.org. Retrieved on: 24 June 2013.

UNSCEAR. 2014. Report to assembly with scientific annexes. New York: UNSCEAR.

Venoso G, De Cicco F, Flores B, Gialanella L, Pugliese M, Roca V, Sabbarese C. 2009. Radon concentrations in schools of the Neapolitan area. Radiat. Meas. 44: 127-130.

WHO. 2009. Handbook on indoor radon: a public health perspective, ISBN 9789241547673.

Cite this article as: Otoo F, Darko EO, Garavaglia M, Giovani C, Pividore S, Andam AB, Amoako JK, Adukpo OK, Tandoh JB, Inkoom S. 2018. Seasonal indoor radon studies in buildings of Accra Metropolis of Greater Accra region of Ghana. Radioprotection 53(3): 199-206 